GLOBAL WATER PATHOGEN PROJECT

PART FOUR. MANAGEMENT OF RISK FROM EXCRETA AND WASTEWATER

\title{
ANAEROBIC SLUDGE BLANKET REACTORS
}

Stewart Oakley

California State University, Chico

Chico, United States

Marcos von Sperling

Federal University of Minas Gerais

Belo Horizonte, Brazil

Matthew Verbyla

San Diego State University

San Diego, United States 


\section{Copyright:}

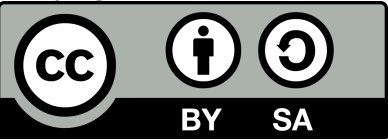

This publication is available in Open Access under the Attribution-ShareAlike 3.0 IGO (CC-BY-SA 3.0 IGO) license (http://creativecommons.org/licenses/by-sa/3.0/igo). By using the content of this publication, the users accept to be bound by the terms of use of the UNESCO Open Access Repository (http://www.unesco.org/openaccess/terms-use-ccbysa-en).

\section{Disclaimer:}

The designations employed and the presentation of material throughout this publication do not imply the expression of any opinion whatsoever on the part of UNESCO concerning the legal status of any country, territory, city or area or of its authorities, or concerning the delimitation of its frontiers or boundaries. The ideas and opinions expressed in this publication are those of the authors; they are not necessarily those of UNESCO and do not commit the Organization.

\section{Citation:}

Oakley, S., von Sperling, M., Verbyla, M. (2017). Anaerobic Sludge Blanket Reactors. In: J.B. Rose and B. Jiménez-Cisneros (eds), Water and Sanitation for the 21st Century: Health and Microbiological Aspects of Excreta and Wastewater Management (Global Water Pathogen Project). (J.R. Mihelcic and M.E.

Verbyla (eds), Part 4: Management Of Risk from Excreta and Wastewater - Section: Sanitation System Technologies, Pathogen Reduction in Sewered System Technologies), Michigan State University, E. Lansing, MI, UNESCO. https://doi.org/10.14321/waterpathogens.61

Acknowledgements: K.R.L. Young, Project Design editor; Website Design: Agroknow (http://www.agroknow.com)

Last published: March 21, 2018 


\section{Summary}

Upflow anaerobic sludge blanket (UASB) reactors and anaerobic baffled reactors (ABRs) are sanitation technologies that are designed to remove organic matter (measured as BOD or COD). They can also recover methane, which can be managed to produce energy. They are considered sludge blanket reactors because the influent wastewater receives treatment by passing through flocculent or granular sludge blankets. These sanitation technologies are part of a centralized or semi-centralized treatment plant for a sewered sanitation system. Anaerobic sludge blanket reactors replace conventional primary and secondary treatment with sludge digestion, but the resulting sludge will contain pathogens that requires posttreatment to meet most regulatory guidelines for safe disposal or reuse. The removal of pathogens and several water quality constituents is not particularly high in this type of sanitation technology; therefore, they require posttreatment, which can be readily accomplished using other sanitation technologies, such as waste stabilization ponds, media filters, and/or constructed wetlands. A UASB reactor is expected to provide 0.8 to $1.6 \log _{10}$ removal for bacterial pathogens, negligible to $0.7 \log _{10}$ removal for viruses, 0.3 $\log _{10}$ removal for protozoan pathogens (based on only one study), negligible to $1.0 \log _{10}$ removal for helminth eggs, and 0.4 to $2.2 \log _{10}$ removal for fecal indicator bacteria. There is less information available for ABRs.

\section{ANAEROBIC SLUDGE BLANKET REACTORS}

\subsection{Brief Technology Description}

In vertical flow UASB and EGSB reactors, a sludge blanket floats as the wastewater passes through it, as illustrated in Figure 2a; in an ABR, the sludge blanket moves upward and downward through the compartments as the wastewater flows through the reactor, as shown in Figure $2 \mathrm{~b}$. The upper part of a UASB reactor contains a solid-gas-liquid separator, which allows biogas to be collected in one compartment and solids to settle and return to the reactor body. This configuration increases the biomass concentration. EGSB reactors are similar to UASB reactors, with the main difference being that EGSB reactors are taller, have a higher height to diameter ratio, and include the recirculation of a portion of the wastewater in order to get better contact between the sludge blanket and the influent wastewater. However, EGSB reactors are less used than UASB reactors for the treatment of domestic wastewater., This section will concentrate on UASB and ABR reactors because of their wide applicability with more emphasis on UASBs because of greater data availability (Figures 3 and 4).

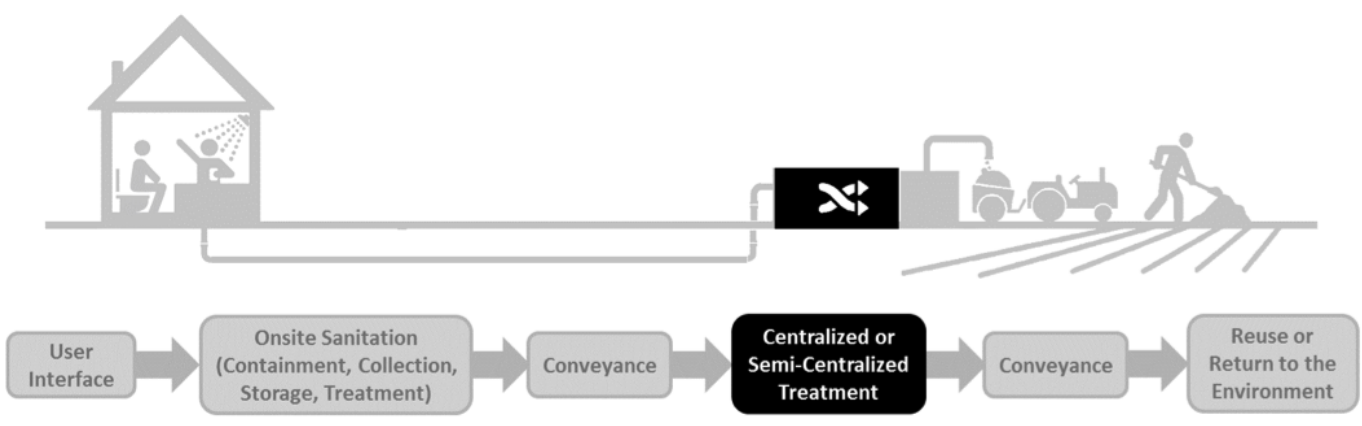

Figure 1. Location where anaerobic sludge blanket reactors are used within the sanitation service chain 
In vertical flow UASB and EGSB reactors, a sludge blanket floats as the wastewater passes through it, as illustrated in Figure 2a; in an ABR, the sludge blanket moves upward and downward through the compartments as the wastewater flows through the reactor, as shown in Figure $2 \mathrm{~b}$. The upper part of a UASB reactor contains a solid-gas-liquid separator, which allows biogas to be collected in one compartment and solids to settle and return to the reactor body. This configuration increases the biomass concentration. EGSB reactors are similar to UASB reactors, with the main difference being that
EGSB reactors are taller, have a higher height to diameter ratio, and include the recirculation of a portion of the wastewater in order to get better contact between the sludge blanket and the influent wastewater. However, EGSB reactors are less used than UASB reactors for the treatment of domestic wastewater., This section will concentrate on UASB and ABR reactors because of their wide applicability with more emphasis on UASBs because of greater data availability (Figures 3 and 4).

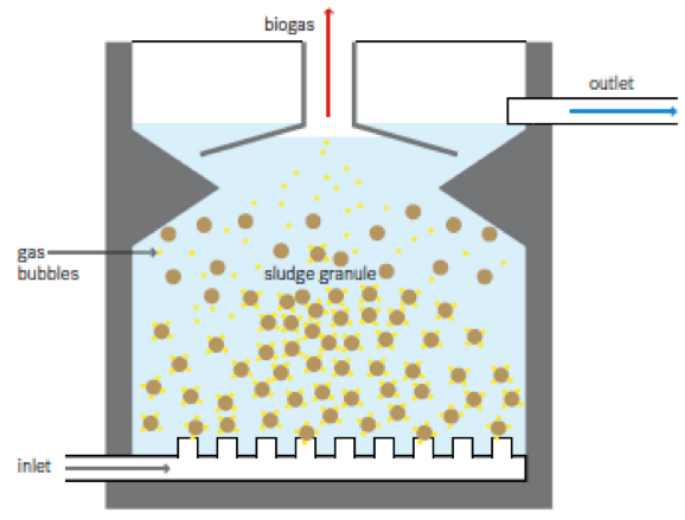

(a)

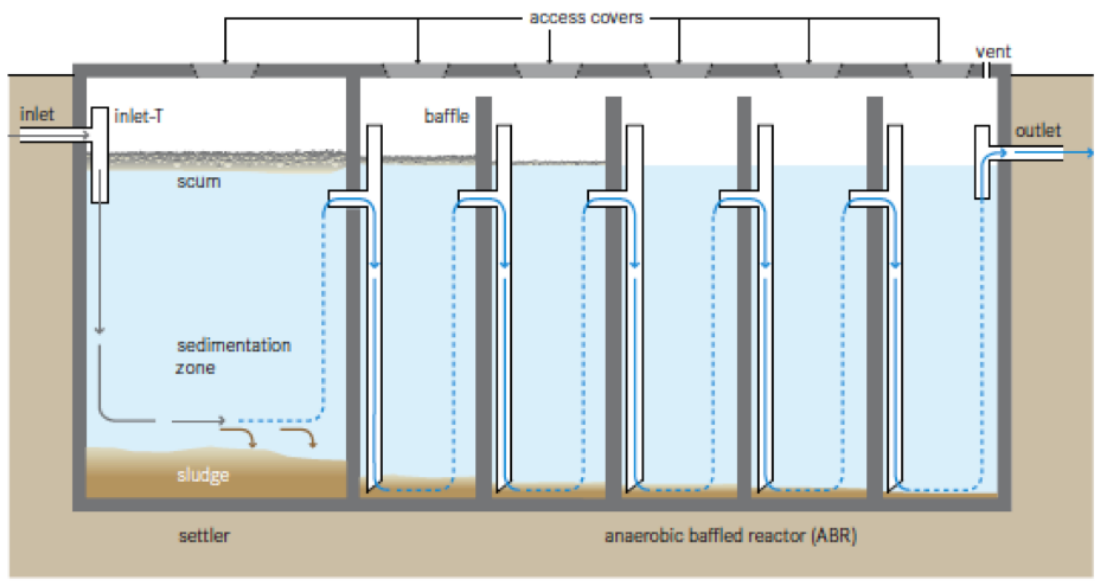

(b)

Figure 2. Anaerobic sludge blanket reactors: a) Upflow anaerobic sludge blanket (UASB), where the sludge blanket floats above the influent as a result of the liquid upflow velocity; and b) Anaerobic baffled reactors (ABR), where the sludge blanket moves from one upflow/downflow compartment to the next. Both reactors require periodic sludge wasting and sludge dewatering processes. Reprinted with permission of Eawag: Swiss Federal Institute of Aquatic Science and Technology, Department Water and Sanitation in Developing Countries (Sandec). Figure from Tilley, E., Ulrich, L., Lüthi, C., Reymond, Ph. and Zurbrügg, C., 2014. Compendium of Sanitation Systems and Technologies. 2nd Revised Edition. Swiss Federal Institute of Aquatic Science and Technology (Eawag). Dübendorf, Switzerland. 


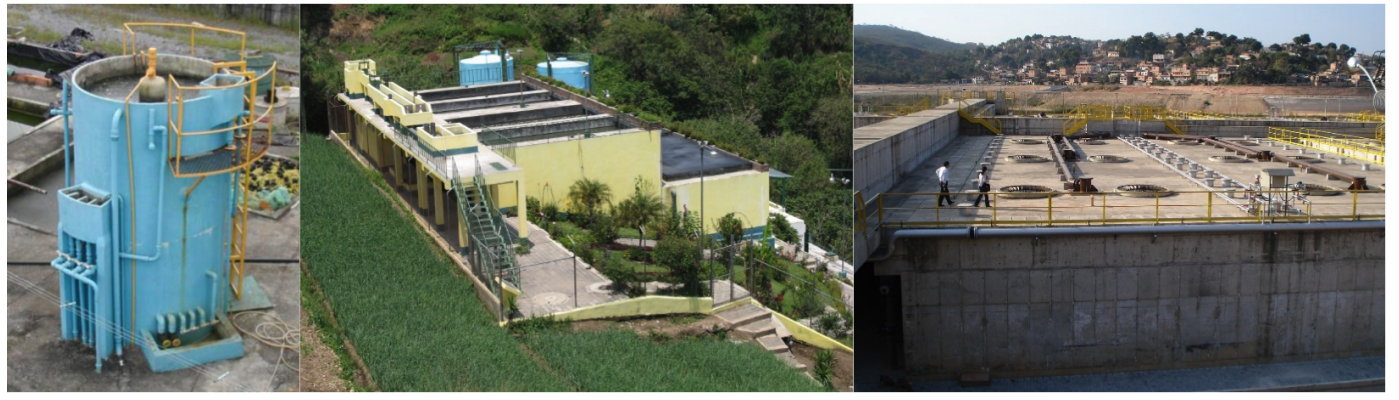

Figure 3. Upflow anaerobic sludge blanket (UASB) reactors used for different population ranges: left: hundreds of inhabitants (Belo Horizonte, Brazil, followed by maturation ponds); middle: thousands of inhabitants (Sololá, Guatemala, followed by a trickling filter with biogas storage tanks); right: one million inhabitants (Belo Horizonte, Brazil, also followed by trickling filters) (middle photo reproduced with permission of Stewart Oakley; left and right photos reproduced with permission of Marcos von Sperling).

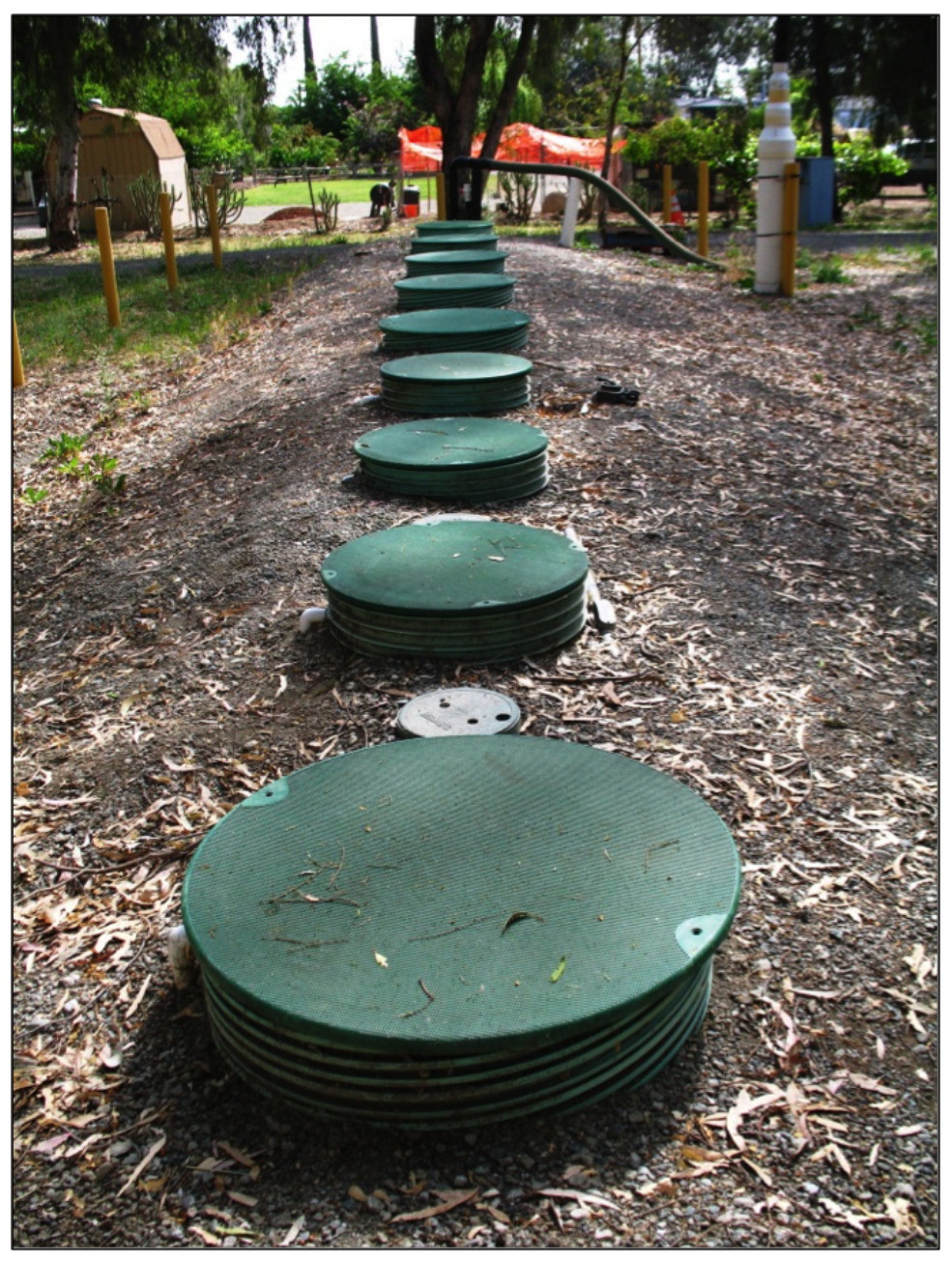

Figure 4. A nine compartment anaerobic baffled reactor (ABR) in operation, Dunnigan, California, USA (photo reproduced with permission of Stewart Oakley). 
The removal of pathogens and several water quality constituents is not particularly high in UASBs and ABRs; therefore, they require post-treatment, which can be readily accomplished using technologies described in other chapters such as: Media Filters, Waste Stabilization Ponds, and Constructed Wetlands, or other technologies in combination with disinfection. Anaerobic sludge blanket reactors produce from 0.1 to $0.2 \mathrm{~kg}$ of dry sludge per $\mathrm{m}^{3}$ of treated wastewater. Sludge granules and flocs that remain suspended in the blanket should be retained in the system, as they provide a surface for the growth of beneficial microbial communities. A fraction of the sludge in the blanket must be withdrawn at specified intervals depending on the solids retention time (SRT) design, and this sludge must be dewatered and treated before reuse or land application. Dewatering is most commonly accomplished using sludge drying beds (Figure 5) in small to medium-size communities, or mechanical dewatering, in medium to large-size communities. Detailed information on the design and operation of anaerobic sludge blanket reactors can be found in Chernicharo (2007), Metcalf \& Eddy and AECOM (2014), and Foxon et al. (2006).

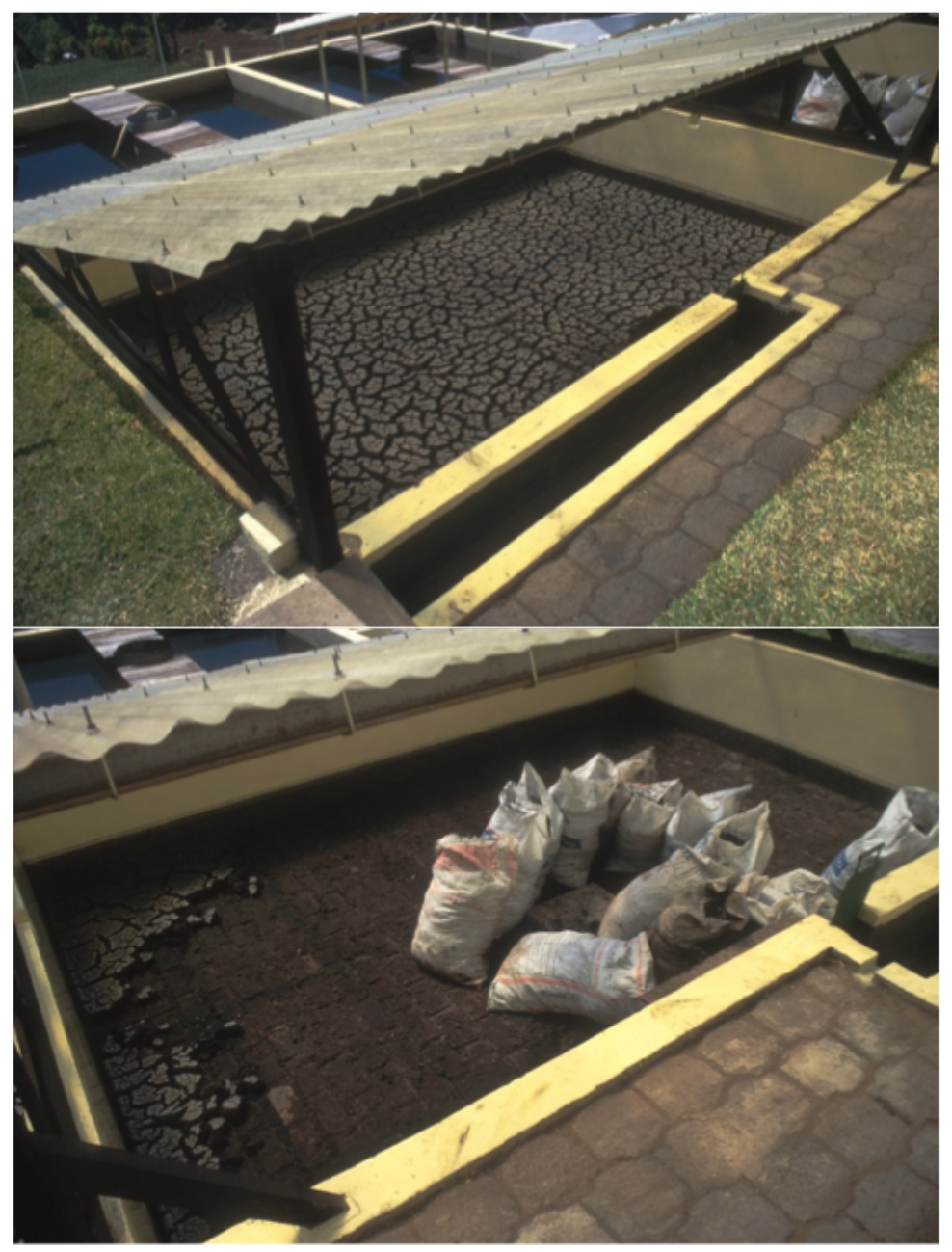

Figure 5. Sludge drying beds for the wasted upflow anaerobic sludge blanket (UASB) sludge at Sololá, Guatemala. The sludge is well digested and dried and is currently provided to the public in bags as a soil conditioner and fertilizer. This practice should be prohibited until there is sufficient removal of pathogens in the sludge. Dewatered sludge should be treated for pathogen removal prior to reuse (see Sludge Management Chapter) (photos reproduced with permission of Stewart Oakley). 


\subsection{Inputs and Outputs for Anaerobic Sludge Blanket Reactors}

Figure 6 presents the typical inputs and outputs of anaerobic sludge blanket reactors. Anaerobic sludge blanket reactors can be used to treat a variety of waste streams, and the inputs may vary from system to system. These reactors are most commonly used to treat industrial wastewater, domestic wastewater, or a mixture of the two. Some systems may also receive landfill leachate. Manure and other agricultural waste are sometimes added to anaerobic reactors in rural areas. Anaerobic sludge blanket reactors are used in place of primary and secondary wastewater treatment and anaerobic sludge digestion, so they receive wastewater that has only gone through screening and grit removal; their effluents, however, still have relatively high $\mathrm{BOD}_{5}$ concentrations as compared with conventional secondary treatment (50-70\% removal as compared with $85-95 \%$ removal for trickling filters or activated sludge) and require post-treatment, typically with aerobic processes and disinfection, to meet discharge or reuse requirements (Chernicharo, 2007). Typical concentrations for pathogens in common input waste streams are provided in the Introduction Chapter. The outputs from anaerobic sludge blanket reactors include treated effluent (liquid), digested sludge (biosolids), and biogas (which can be captured and can be used as a fuel for cooking or heating in small plants, and electricity generation in large ones). Treated effluent is continuously discharged from these reactors, biogas is continuously produced, and digested sludge must be withdrawn periodically.

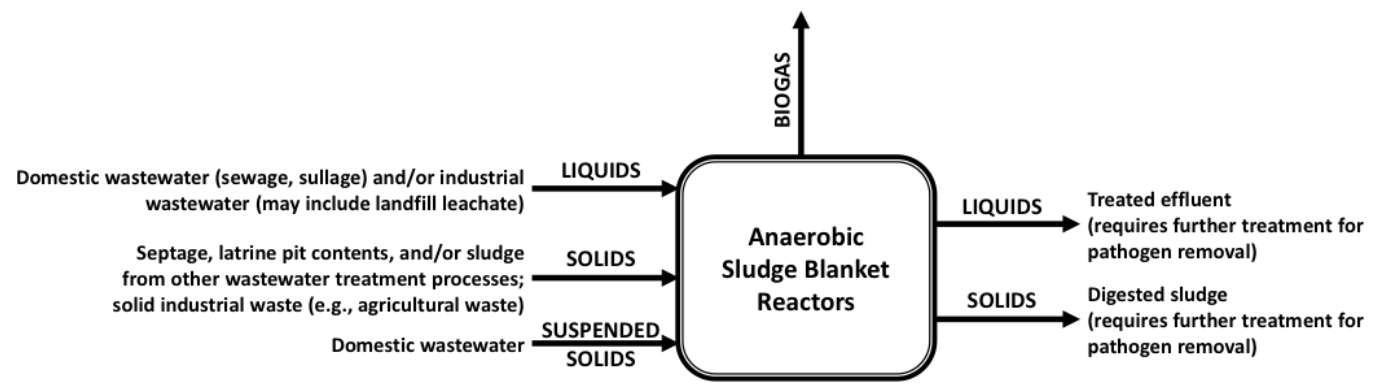

Figure 6. Typical inputs and outputs for anaerobic sludge blanket reactors

\subsection{Factors Affecting Pathogens in Anaerobic Sludge Blanket Reactors}

Anaerobic wastewater treatment processes are designed specifically for organic matter stabilization (i.e., reduction in $\mathrm{BOD}$ and $\mathrm{COD}$ ) and methane production; therefore, any removal or inactivation of viral, bacterial, protozoan or helminth pathogens in treated effluents or sludge is incidental to the design objectives. Nevertheless, the reduction of viral, bacterial, protozoan, and helminth pathogens has been reported to range from negligible to $1.5 \log _{10}$ units for UASBs (WHO, 2006).

A summary of the most important factors for removal of the different pathogen types is presented in Tables 1a and $1 \mathrm{~b}$. The principal removal mechanism for pathogens in anaerobic sludge blanket reactors is retention in the sludge and removal via sludge withdrawal, although some pathogens may also be inactivated due to physical-chemical factors (Figure 7). The retention of pathogens in the sludge may occur due to physical filtration as wastewater passes through the dense layer in the sludge blanket, or due to microbiological factors-pathogens may be retained in the sludge blanket by the same mechanisms that cause the formation of granular sludge (Chernicharo, 2007; Metcalf \& Eddy AECOM, 2014). Very few studies have been performed to determine the impact of individual mechanisms for pathogen removal in UASBs and ABRs; most studies simply report the differences in influent and effluent concentrations. 
Table 1a. Summary of factors and mechanisms for pathogen removal in anaerobic sludge blanket reactor effluent: Retention in the sludge

\section{Summary of removal mechanism}

Retention in the sludge is the primary mechanism responsible for the removal of pathogens from wastewater treated in anaerobic sludge blanket reactors. Helminth eggs with settling velocities much greater than $0.5 \mathrm{~m} / \mathrm{h}$ (e.g., Schistosoma spp.) could potentially be removed by sedimentation. One mechanism that may cause pathogen retention in sludge is their attachment to microbial extracellular polymeric substances in sludge blanket granules, but this has not been well-studied.

\section{Factors}

contributing to

Viruses

Bacteria

Protozoa

Helminths

removal

\section{$0.7 \log _{10}$ removal of} human adenovirus

Some important factors for the retention of pathogens in anaerobic reactor sludge include:

- upflow velocities

- contact time with settled sludge and sludge blanket

- sludge retention time in reactor

- turbulence due to biogas production

\section{$0.2 \log _{10}$ removal of} norovirus GII in a UASB at a hospital in Rio de Janeiro, Brazil.

No removal for rotavirus group A (Prado et al., 2011)

Adenovirus qPCR copies and culturable enterovirus were more volumetrically concentrated in UASB reactor sludge than they were in the wastewater

(Symonds et al., 2014; Verbyla, 2015).
$1.0 \log _{10}$ removal for

Salmonella spp., 0.5

$\log _{10}$ removal for

Shigella spp., $1.0 \log _{10}$ removal for Vibrio spp in

a UASB reactor (Pant and Mittal, 2007)

$1.1 \log _{10}$ reduction of thermotolerant coliforms

in UASB reactors

(Oliveira and von

Sperling, 2011)

$1.0 \log _{10}$ reduction of thermotolerant coliforms in an ABR reactor (Lalbahadur et al., 2005)
0.42 to $1.30 \log _{10}$ for UASBs (Keller et al., 2004; von Sperling et

$0.3 \log _{10}$ removal of Cryptosporidium oocysts (Morsy et al. 2007)

al., 2003; Yaya-Beas et al., 2015).

$1.66 \log _{10}$ for an eight compartment ABR with a 42 hour hydraulic retention time (Foxon et al., 2006).

Table 1b. Summary of factors and mechanisms for pathogen removal in anaerobic sludge blanket reactor effluent: Other potential physical-chemical factors

\section{Other Factors}

Evidence of Pathogen Vulnerabilty

Other potential physical-chemical factors include temperature, reaction times, $\mathrm{NH}_{3}$ toxicity, and volatile fatty acid toxicity.

- Higher temperatures in reactors increase the rate of other pathogen inactivation mechanisms; UASBs and ABRs, however, are mostly operated at ambient temperatures, thus minimizing temperature effects

- Short hydraulic retention times limit reaction times for pathogen inactivation

- Uncharged aqueous ammonia (NH3) has microbiocidal effects, especially at There are no supporting data for these possible removal mechanisms for viruses, bacteria, protozoa or helminths high $\mathrm{pH}$ values (when this form of ammonia is present in high concentrations); however, the $\mathrm{pH}$ levels encountered in anaerobic sludge blanket reactors are typically much more neutral, supporting the formation of NH4+.

- Volatile fatty acids have microbiocidal effects at low $\mathrm{pH}$ values; however, the $\mathrm{pH}$ levels encountered in anaerobic sludge blanket reactors are typically near neutral, potentially minimizing these effects. 


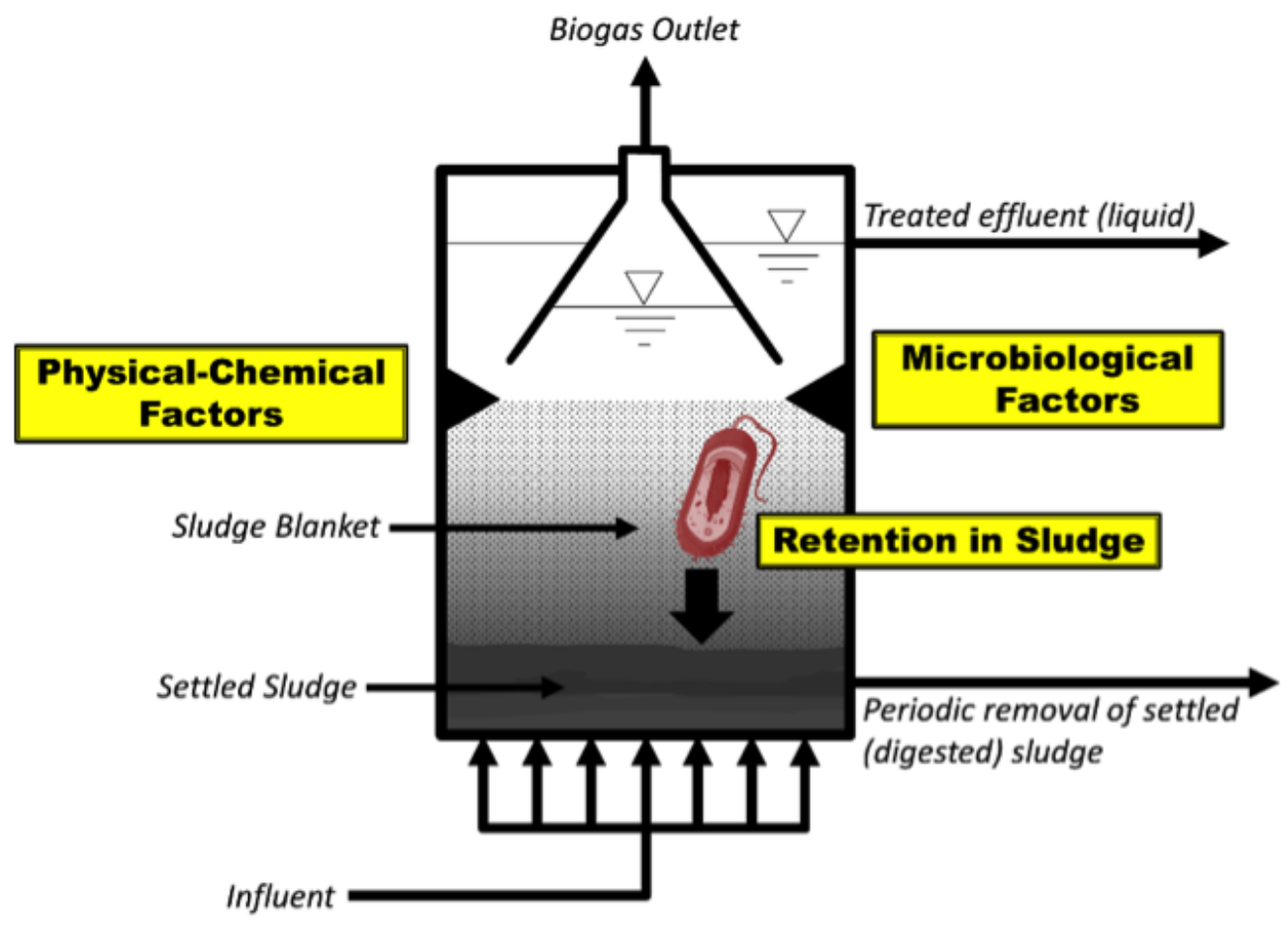

Figure 7. M ajor factors affecting pathogen fate in anaerobic sludge blanket reactors

\subsection{Retention in Sludge}

There is a scarcity of data in the literature on the mechanisms of pathogen retention in sludge from anaerobic sludge blanket reactors. As a result, it is assumed that pathogen retention in sludge is similar to the processes retaining biomass in anaerobic sludge blanket reactors. These processes include Chernicharo, 2007; Metcalf \& Eddy AECOM, 2014):

- Attachment of microorganisms to other cells or organic solids

- Flocculation due to bacterial growth
- Interstitial retention of bacteria passing through sludge blanket

- Adsorption of microorganisms or colloidal particles by reversible physiochemical forces

- Irreversible attachment of microorganisms by microbial extracellular polymers

- Granulation and multiplication of bacterial cells by substrate diffusion into the granular structure

Verbyla (2015) measured the quantities of human adenovirus using qPCR in samples collected from the influent, effluent, sludge blanket, and settled sludge of a full-scale UASB reactor in Brazil, separating samples into a 
pellet (larger, settleable solids) and a supernatant (liquid and non-settleable solids) by centrifugation for $10 \mathrm{~min}$. at $1,157 \times g$. The concentrations of adenovirus in the liquid supernatant were similar in samples collected at the effluent and from the sludge blanket; however, concentrations per dry mass in the pellet from the sludge blanket samples were more than an order of magnitude greater than they were in the pellet of the treated effluent, indicating that the viruses were volumetrically concentrated in the sludge. Verbyla (2015) also found that the concentrations of adenovirus per dry weight of solids in the sludge blanket and in the settled sludge were similar, which indicated that retention in the sludge and removal of settled sludge might be one mechanism for the removal of adenovirus in UASB reactors.

\subsection{Physical-Chemical and Microbiological Factors}

There has been limited research into the specific impact of physical-chemical and microbiological factors on the inactivation of pathogens retained in UASB and ABR reactors. Therefore, it is assumed that the factors that are most relevant for pathogen removal and inactivation in these systems are similar to the factors responsible for pathogen removal in anaerobic reactors (i.e., digesters) used to treat primary and biological sludge from other wastewater treatment systems (see Chapter on Sludge Management). In particular, pathogens may be vulnerable to toxicity from metabolites naturally present in wastewater and its sludge, such as $\mathrm{NH}_{3}$, amines, aldehydes, ketones, volatile fatty acids (Acquisto et al., 2006). This may cause pathogens to be present in the treated effluent, but in nonviable forms. For example, Foxon (2009) found no difference in the overall concentration of Ascaris eggs in pilot-scale ABR with 8 compartments and 20 hour hydraulic retention time, but the percentage of viable eggs was reduced from $36 \%$ at the influent to only $2 \%$ in the treated effluent. Higher temperatures can also accelerate the natural die-off of pathogens in anaerobic reactors, especially if they are retained in the system for a long time. Compared to other pathogen types, helminth eggs are very resistant to high temperatures, and may enter a dormancy stage to maintain viability in anaerobic environments. Authors of one study found that Ascaris eggs became dormant (remained unembryonated) when exposed to the anaerobic environment in a $35^{\circ} \mathrm{C}$ lab-scale anaerobic digester and $65 \%$ maintained viability for up to 16 days (Manser et al., 2015). The authors reported that of the Ascaris eggs that were initially exposed to aerobic conditions (to trigger their initial stages of development), only $35 \%$ maintained viability after 16 days once they entered the anaerobic digester.

The sedimentation of pathogens not retained in sludge particles from anaerobic sludge blanket reactors has not been specifically studied, but may be minor. The experimentally measured settling velocity for helminth eggs in tap water was found to average $0.22 \mathrm{~m} / \mathrm{h}$ for Ascaris and $0.54 \mathrm{~m} / \mathrm{h}$ for Trichuris (Sengupta et al., 2011); and settling velocities for protozoa, and especially bacteria and viruses, would be much lower (Cizek et al., 2008; David and
Lindquist, 1982; Kulkarni et al., 2004; Medema et al., 1998). Design guidelines for liquid upflow velocities in UASB reactors indicate that they should be $0.5-0.7 \mathrm{~m} / \mathrm{h}$ during average flow conditions and no more than $1.5 \mathrm{~m} / \mathrm{h}$ during peak flow conditions (Chernicharo, 2007). Furthermore, the design upflow velocity is calculated using the interior reactor diameter and the flow rate. In reality, the volume occupied by sludge blanket granules acts as hydraulic dead space, meaning that the actual velocity of the liquid moving through the reactor can be slightly greater (Bolle et al., 1986). Therefore, it is likely that "free floating" helminths would exit the reactor in the liquid effluent, reinforcing that the major mechanism is retention in sludge blanket or attachment to sludge granules with sedimentation playing a minor role.

Tables $1 \mathrm{a}$ and $1 \mathrm{~b}$ present summaries of what is known about the mechanisms associated with pathogen removal in anaerobic sludge blanket reactors.

\subsection{Design, Operation, and Maintenance Guidelines for Pathogen Removal}

From a design perspective, not much can be done to enhance the removal of pathogens in anaerobic sludge blanket reactors, as they are primarily designed to remove soluble and suspended organic matter (i.e., BOD and COD). The design engineer should ensure that systems using these reactors are equipped with appropriate posttreatment technologies and sludge treatment systems to remove pathogens from effluent and sludge to the extent necessary for safe reuse. Shallow $(<1 \mathrm{~m})$ and/or baffled polishing ponds have been reported to be effective posttreatment technologies for the removal of helminth eggs and fecal indicator bacteria from UASB reactor effluent (Cavalcanti et al., 2001; Dias et al., 2014; Khan et al., 2011; von Sperling and Mascarenhas, 2005; von Sperling et al., $2005,2003,2002)$. The depth of the polishing pond is important for enhancing pathogen removal. For example, a community-managed wastewater treatment system in Bolivia with a UASB reactor and deeper (unbaffled) polishing ponds showed limited removal of helminth eggs, Giardia, and viruses (Symonds et al., 2014; Verbyla et al., 2013). Khan et al. (2011) also reported good removal of helminth eggs in an overland flow system treating UASB reactor effluent.

There are several operational concerns that can lead to reduced pathogen removal in well-designed anaerobic sludge blanket reactors. Hydraulic overloading, high upflow velocities, excessive sludge accumulation, and solids loss due to gas production can result in the discharge of solids and retained pathogens in the treated effluents. The most important way to maximize pathogen removal and minimize microbial risks for wastewater treatment systems with UASBs, EGSBs and ABRs is to ensure proper design, operation, maintenance, and the safe treatment and management of sludge. Due to their small volumes and short retention times, UASBs, EGSBs, and ABRs are not very robust to short-term fluctuations in wastewater flow and quality. Changing conditions may cause sludge granules to spontaneously disintegrate (Liu et al., 2004), potentially releasing pathogens retained in the sludge. 
Trained and experienced operators are required to ensure that the systems perform well; in one study, it was reported that 15 different anaerobic sludge blanket reactor systems in India failed their discharge standards despite the fact that they were well-designed and had been in operation for less than 7 years (Sato et al., 2006).

Table 2 presents a summary of key factors associated with the removal of the four major groups of pathogenic organisms in anaerobic sludge blanket reactors, indicating whether the factor enhances or reduces removal. Considering that sludge drying beds are widely used for dewatering the sludge removed from anaerobic reactors, the key factors associated with pathogen removal in the sludge treatment unit are described in Table 3 and in further depth in Chapter on Sludge Management.

Table 2. Summary of key factors for pathogen removal in anaerobic sludge blanket reactors

\section{Factor}

Upflow Velocity (for UASBs and EGSBs)

Baffle Configuration (for ABRs)

Temperature

Retention in Sludge Blanket and Periodic Sludge Removal

Hydraulic Overloading

Excessive Sludge Accumulation (causing loss of solids)

Gas Production (causing loss of solids)

Post-Treatment
Pathogen removal is potentially $\uparrow$ enhanced or $\downarrow$ reduced under the following conditions:

Lower upflow velocities $=\uparrow$ Pathogen Removal Proper Baffle Configuration $=$ Minimized Solids Loss $=\uparrow$ Pathogen Removal

Higher Temperature $=\uparrow$ Pathogen Removal Well-Developed Sludge Bed $=\uparrow$ Pathogen Retention Removal of Sludge $=\uparrow$ Pathogen Removal Hydraulic Overloading $=\downarrow$ Pathogen Removal Excessive Sludge $=\downarrow$ Pathogen Removal More Solids Loss $=\downarrow$ Pathogen Removal UASBs, EGSBs, or ABRs without post treatment do not provide sufficient pathogen removal

Table 3. Summary of key strategies to reduce microbial risk from sludge drying beds used with anaerobic sludge blanket reactors (See also Chapter on Sludge Management)

Factor Pathogen Removal is Potentially $\uparrow$ Enhanced or $\downarrow$ Reduced Under the Following Conditions:

\begin{tabular}{lr}
\hline Temperature & Higher Temperature $=\uparrow$ Pathogen Removal \\
$\mathrm{pH}$ & Higher $\mathrm{pH}$ (lime application) $=\uparrow$ Pathogen Removal \\
Humidity & Roofed Drying Bed $=\uparrow$ Pathogen Removal \\
Time & Longer Time in Drying Bed $=\uparrow$ Pathogen Removal \\
Inappropriate Use & Sludge removed from drying beds should be monitored for helminth eggs and other \\
pathogens prior to reuse
\end{tabular}

The range of pathogen reduction reported in the literature for UASB reactors is generally between zero and $2 \log _{10}$ units for bacteria, and less than $1 \log _{10}$ unit for other pathogens (Figure 8). The most commonly reported pathogen removed in UASB and ABR systems has been helminth eggs, principally those of Ascaris. Studies from Brazil have reported helminth egg removals ranging from 0.42 to $0.92 \log _{10}$ units in UASB reactors from full scale wastewater treatment plants (von Sperling et al., 2005),

\subsection{Data on Fecal Indicator and Pathogen Removal in Anaerobic Reactors}

with influent concentrations ranging from 17 to 254 eggs/L and effluent concentrations ranging from 3 to 37 eggs/L (Keller et al., 2004; von Sperling et al., 2003). A laboratory study on UASB reactor operation at low temperature (11-14 ${ }^{\circ} \mathrm{C}$ ) in Peru reported helminth egg removals ranging from 0.96 to $1.30 \log _{10}$ units, with effluent concentrations ranging from 5 to 35 eggs/L, and found that removal was independent of upflow velocities in the reactor for velocities between $0.12-0.41 \mathrm{~m} / \mathrm{h}$ (Yaya-Beas et al., 2016). The removal of helminth eggs in UASB reactors with hydraulic retention times between 6 - 8 hours was equal to or greater than the removal of helminth eggs with retention times between $4-6$ hours (Figure 8). 


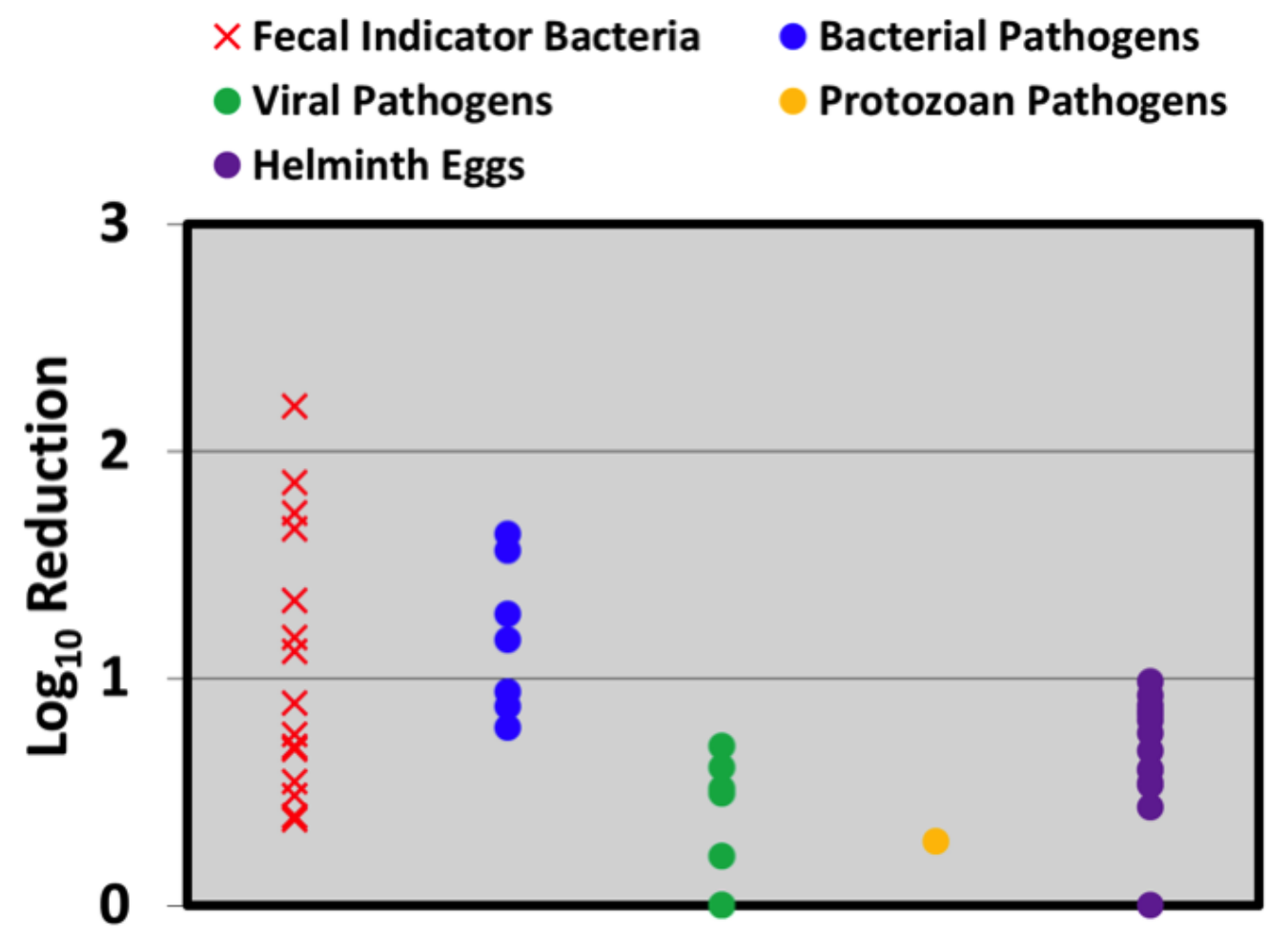

Figure 8. Log10 reduction values for pathogens and fecal bacteria (including E. coli and fecal streptococci) in UASB reactors. Data sources: (Chernicharo et al. 2001; Dixo et al. 1995; Prado et al. 2011; Soares et al. 2000; von Sperling et al. 2002; 2003; 2005; Keller et al. 2004; Ribeiro et al. 2015; El-Khateeb et al. 2009; Morsy et al. 2007; Trein et al. 2015; Gonçalves et al. 2009; Dias 2016; Verbyla 2015; Symonds et al. 2014; Pant and Mittal 2007).

In one of the few studies reporting pathogen removal in ABRs, Foxon et al. (2006) reported a $1.66 \log _{10}$ removal of Ascaris spp. from treated effluent for an eight compartment pilot scale ABR, with mean influent and effluent concentrations of 772 and 17 eggs/L, respectively. This is the highest removal for helminths reported in the literature for sludge blanket reactors. It may be attributed to enhanced liquid phase contact with the sludge blanket by passing through multiple upflow/downflow compartments coupled with a long hydraulic retention time (44 hours) (Foxon et al., 2006).

Pathogen removal in UASB reactors has also been published in very few studies, but the findings to date indicate that reduction is below $1 \log _{10}$ for all pathogens, perhaps with the exception of bacterial pathogens and other fecal bacteria. Prado et al. (2011) reported a $0.7 \log _{10}$ removal for human adenovirus, a $0.2 \log _{10}$ removal for norovirus GII, and no removal for rotavirus group A. Symonds et al. (2014) reported negligible removal of rotavirus and norovirus GI for a UASB reactor in the remote Yungas region of Bolivia (based on only two 24-hour composite samples, measured using RT-qPCR); they reported a $0.5 \log _{10}$ reduction of culturable enteric viruses (on BGMK cells) in the same system (based on only a single pair of 24-hour composite samples). Verbyla (2015) found up to $0.6 \log _{10}$ removal of human adenovirus (using qPCR) for three different UASB reactors in Brazil, based on $4-6$ samples collected biweekly. Only one study was found regarding the removal of protozoan pathogens in UASB reactors; Morsy et al. (2007) reported 0.3- $\log _{10}$ reduction of Cryptosporidium oocysts.

There are several studies on the removal of fecal indicator bacteria (mostly coliforms) in UASBs but very few on the removal of actual bacterial pathogens. In general, the removal of fecal bacteria appears to be a bit greater than the removal of viral, protozoan, and helminth pathogens. Pant and Mittal (2007) found a $0.94 \log _{10}$ removal for Salmonella spp., a $0.78 \log _{10}$ for Shigella spp., and a $0.87 \log _{10}$ for Vibrio spp.; they also reported a 0.69 $\log _{10}$ removal for thermotolerant coliforms and a $0.75 \log _{10}$ for fecal streptococci. El-Khateeb et al. (2009) reported more efficient reduction of fecal bacteria in a UASB reactor in Egypt, with removals of more than $1 \log _{10}$ for total and thermotolerant coliforms, fecal streptococci, Pseudomonas aeruginosa, Listeria monocytogenes, salmonella, and staphylococci. 


\subsection{Data on Pathogens in Sludge from Anaerobic Reactors}

UASB reactors produce sludge at a rate of $0.1-0.2$ $\mathrm{kg} / \mathrm{m}^{3}$ (dry mass solids) of domestic wastewater treated, and this sludge must be removed from the reactor every few weeks to maintain proper operating conditions. Prior to reuse, the sludge must be dewatered and treated, as it still contains high concentrations of pathogens (Chernicharo, 2007).

\subsection{Conclusions}

Anaerobic sludge blanket reactors are designed with the main objective of removing organic matter and providing some digestion of sludge, therefore the removal of pathogens in these reactor is not particularly high. The wastewater and sludge outputs from these reactors require some type of additional treatment to reduce the concentrations of pathogens prior to their discharge or reuse for beneficial purposes. Table 4 presents a summary of the removal of three types of pathogens from wastewater in anaerobic sludge blanket reactors, derived from the literature (no literature data were found for removal of protozoan pathogens in these systems). Table 5 presents concentrations of pathogens in the sludge.

Table 4. Summary of indicators and pathogen removal from wastewater in anaerobic reactors

\begin{tabular}{|c|c|c|c|c|c|}
\hline \multicolumn{6}{|c|}{$\begin{array}{c}\text { Average Reported Pathogen and Fecal Indicator log10 } \\
\text { Removal Values }^{\mathbf{a}} \text { (Ranges Shown in Parentheses) }\end{array}$} \\
\hline $\begin{array}{l}\text { Type of } \\
\text { Reactor }\end{array}$ & $\begin{array}{c}\text { Bacterial } \\
\text { Pathogens }\end{array}$ & Viruses & Protozoa & Helminth Eggs & $\begin{array}{c}\text { Fecal Indicator } \\
\text { Bacteria } \\
\text { (including } E \text {. } \\
\text { coli) }\end{array}$ \\
\hline UASB Reactor & $\begin{array}{c}1.2 \\
(0.8 \text { to } 1.6)\end{array}$ & $\begin{array}{c}0.3 \\
\text { (negligible to } \\
0.7 \text { ) }\end{array}$ & 0.3 & $\begin{array}{l}0.7 \\
\text { (negligible to 1) }\end{array}$ & $\begin{array}{c}1.1 \\
(0.4 \text { to } 2.2)\end{array}$ \\
\hline Anaerobic Baffled Reactor & $\mathrm{ND}^{\mathrm{b}}$ & ND & ND & 1.7 & $\sim 1$ \\
\hline
\end{tabular}

a Sources: (Chernicharo et al. 2001; Dixo et al. 1995; Prado et al. 2011; Soares et al. 2000; von Sperling et al. 2002, 2003, 2005; Keller et al. 2004; Ribeiro et al. 2015; El-Khateeb et al. 2009; Morsy et al. 2007; Trein et al. 2015; Gonçalves et al. 2009; Dias 2016; Verbyla 2015; Symonds et al. 2014; Pant and Mittal 2007; Foxon 2009; Foxon et al. 2006; Lalbahadur et al., 2005; Oliveira and von Sperling, 2011; von Sperling and Mascarenhas, 2005; Yaya-Beas et al., 2015)

${ }^{\mathrm{b}} \mathrm{ND}=\mathrm{No}$ data

Table 5. Concentrations of pathogens found in anaerobic reactor sludge

\begin{tabular}{|c|c|c|c|c|}
\hline Pathogen $^{a}$ & Country & Concentration $/ \mathbf{g ~ T S}^{\mathrm{b}}$ & Type of Sludge & References \\
\hline \multicolumn{5}{|l|}{ Helminths } \\
\hline \multirow{2}{*}{ Ascaris (total eggs) } & Brazil & 48 eggs & UASB reactor & Keller et al., 2004 \\
\hline & Mexico & 62.9 eggs & UASB reactor & Rojas Oropeza et al., 2001 \\
\hline Ascaris (viable eggs) & Mexico & 2.9 eggs & UASB reactor & Rojas Oropeza et al., 2001 \\
\hline \multicolumn{5}{|l|}{ Viruses } \\
\hline Culturable enteroviruses & Bolivia & $500 \mathrm{iu}$ & UASB reactor & Symonds et al., 2014 \\
\hline Human adenovirus & Brazil & $1.6 \mathrm{E}+06$ to $3.4 \mathrm{E}+07$ gene copies & UASB reactor & $\begin{array}{c}\text { Authors' own } \\
\text { unpublished data }\end{array}$ \\
\hline
\end{tabular}




\section{References}

Acquisto, B.A., Reimers, R.S., Smith, J.E. and Pillai, S.D. (2006). Factors affecting disinfection and stabilization of sewage sludge. Proceedings of the Water Environment Federation. 2006, Water Environment Federation. pp. 5345-5361.

Bolle, W.L., Van Breugel, J., Van Eybergen, G.C., Kossen, N.W.F. and Zoetemeyer, R.J. (1986). Modeling the liquid flow in up-flow anaerobic sludge blanket reactors. Biotechnology and Bioengineering. 28, Wiley Online Library. pp. 1615-1620.

Cavalcanti, P.F.F., Van Haandel, A. and Lettinga, G. (2001). Polishing ponds for post-treatment of digested sewage part 1: flow-through ponds. Water Science and Technology. 44, IWA Publishing. pp. 237-245.

Chernicharo, C. (2007). Anaerobic Reactors. Biological wastewater treatment Series. 4, IWA Publishing, UK.

Chernicharo, C., Da Silva Cota, R., Zerbini, A.M., von Sperling, M. and Novy de Castro Brito, L.H. (2001). Post-treatment of anaerobic effluents in an overland flow system. Water Science and Technology. 44, IWA Publishing. pp. 229-236.

Cizek, A.R., Characklis, G.W., Krometis, L.A., Hayes, J.A., Simmons, O.D., Di Lonardo, S. et al. (2008). Comparing the partitioning behavior of Giardia and Cryptosporidium with that of indicator organisms in stormwater runoff. Water Research. 42, Elsevier. pp. 4421-4438.

David, E.D. and Lindquist, W.D. (1982). Determination of the specific gravity of certain helminth eggs using sucrose density gradient centrifugation. The Journal of Parasitology. JSTOR. pp. 916-919.

Dias, D.F.C. (2016). Evaluation of Escherichia coli inactivation and sunlight penetration in a shallow maturation pond: hydrodynamics and disinfection. Federal University of Minas Gerais, Brazil.

Dias, D.F.C., Possmoser-Nascimento, T.E., Rodrigues, V.A.J. and Von Sperling, M. (2014). Overall performance evaluation of shallow maturation ponds in series treating UASB reactor effluent: ten years of intensive monitoring of a system in Brazil. Ecological Engineering. 71, pp. 206-214.

Dixo, N.G.H., Gambrill, M.P., Catunda, P.F. and Van Haandel, A.C. (1995). Removal of pathogenic organisms from the effluent of an upflow anaerobic digester using waste stabilization ponds. Water Science and Technology. 31, Elsevier. pp. $275-284$.

El-Khateeb, M.A., Al-Herrawy, A.Z., Kamel, M.M. and El-Gohary, F.A. (2009). Use of wetlands as post-treatment of anaerobically treated effluent. Desalination. 245, Elsevier B.V. pp. 50-59. doi: 10.1016/j.desal.2008.01.071.

Foxon, K.M., Buckley, C.A., Brouckaert, C.J., Dama, P., Mtembu, Z., Rodda, N. et al. (2006). The evaluation of the anaerobic baffled reactor for sanitation in dense peri-urban settlements. Water Research Commission Report. 1248, pp. 4421-4438.

Foxon, K.M. (2009). Analysis of a pilot-scale anaerobic baffled reactor treating domestic wastewater. University of KwaZulu-Natal. Durban.

Gonçalves, H.R.R., da Silveira, D.A., Monteggia, L.O., Basseggio, G. and Miranda, L.A. (2009). Análise do desempenho de sistema integrado, enfatizando lagoa de polimento, tratando efluentes domésticos em condições de variações de temperatura. 8th IWA Specialist Group Conference on Waste Stabilization Ponds.

Keller, R., Passamani-Franca, R.F., Passamani, F., Vaz, L., Cassini, S.T., Sherrer, N. et al. (2004). Pathogen removal efficiency from UASB+ BF effluent using conventional and UV post-treatment systems. Water Science and Technology. 50, IWA Publishing. pp. 1-6.

Khan, A.A., Gaur, R.Z., Tyagi, V.K., Khursheed, A., Lew, B., Mehrotra, I. et al. (2011). Sustainable options of post treatment of UASB effluent treating sewage: a review. Resources, Conservation and Recycling. 55, Elsevier. pp. 1232-1251.

Kulkarni, P., Dutari, G., Biswas, P. and Haught, R. (2004). Gravity settling characteristics of Cryptosporidium parvum oocysts in aqueous suspension using in situ static light scattering. Colloids and Surfaces A: Physicochemical and 
Engineering Aspects. 233, pp. 1-10.

Lalbahadur, T., Pillay, S., Rodda, N., Smith, M., Buckley, C., Holder, F. et al. (2005). Microbiological studies of an anaerobic baffled reactor: microbial community characterisation and deactivation of health-related indicator bacteria. Water Science and Technology. 51, IWA Publishing. pp. 155-162.

Liu, Y.Q., Liu, Y. and Tay, J.H. (2004). The effects of extracellular polymeric substances on the formation and stability of biogranules. Applied Microbiology and Biotechnology. 65, Springer. pp. 143-148.

Manser, N.D., Wald, I., Ergas, S.J., Izurieta, R. and Mihelcic, J.R. (2015). Assessing the fate of Ascaris suum ova during mesophilic anaerobic digestion. Environmental Science and Technology. 49, pp. 3128-3135.

Medema, G.J., Schets, F.M., Teunis, P.F.M. and Havelaar, A.H. (1998). Sedimentation of Free and AttachedCryptosporidium Oocysts and Giardia Cysts in Water. Applied and Environmental Microbiology. 64, pp. 4460-4466.

Mohammed, A.O., Tchobanoglous, G., Stensel, H.D., Tsuchihashi, R. and Burton, A.F. (2014). Wastewater Engineering: Treatment and Resource Recovery. 5th edition McGraw-Hill. New York, USA.

Morsy, E.A., Al-Herrawy, A.Z. and Ali, M.A. (2007). Assessment of Cryptosporidium removal from domestic wastewater via constructed wetland systems. Water, Air, and Soil Pollution. 179, pp. 207-215. doi: 10.1007/s11270-006-9225-8.

Murray, C.J.L., Barber, R.M., Foreman, K.J., Ozgoren, A.A., Abd-Allah, F., Abera, S.F. et al. (2015). Global, regional, and national disability-adjusted life years (DALYs) for 306 diseases and injuries and healthy life expectancy (HALE) for 188 countries, 1990-2013: quantifying the epidemiological transition. Lancet (London, England). 386, pp. 2145-2191. doi: 10.1016/S0140-6736(15)61340-X.

Oliveira, S.C. and von Sperling, M. (2011). Performance evaluation of different wastewater treatment technologies operating in a developing country. Journal of Water, Sanitation and Hygiene for Development. 1, pp. 37-56. doi: 10.2166/washdev.2011.022.

Oropeza, M.R., Cabirol, N., Ortega, S., Ortiz, L.P.C. and Noyola, A. (2001). Removal of fecal indicator organisms and parasites (fecal coliforms and helminth eggs) from municipal biologic sludge by anaerobic mesophilic and thermophilic digestion. Water Science and Technology. 44, IWA Publishing. pp. 97-101.

Pant, A. and Mittal, A.K. (2007). Monitoring of pathogenicity of effluents from the UASB based sewage treatment plant. Environmental Monitoring and Assessment. 133, Springer. pp. 43-51.

Prado, T., Silva, D.M., Guilayn, W.C., Rose, T.L., Gaspar, A.M. and Miagostovich, M.P. (2011). Quantification and molecular characterization of enteric viruses detected in effluents from two hospital wastewater treatment plants. Water Research. 45, pp. 1287-97.

Sato, N., Okubo, T., Onodera, T., Ohashi, A. and Harada, H. (2006). Prospects for a self-sustainable sewage treatment system: A case study on full-scale UASB system in India's Yamuna River Basin. Journal of Environmental Management. 80, Elsevier. pp. 198-207.

Sengupta, M.E., Thamsborg, S.M., Andersen, T.J., Olsen, A. and Dalsgaard, A. (2011). Sedimentation of helminth eggs in water. Water Research. 45, pp. 4651-4660.

Soares, A.M., Zerbini, A.M. and Chernicharo, C.A. (2000). Perfil longitudinal de Escherichia coli e ovos de helmintos em um sistema reator UASB/lagoa de polimento com chicanas. Congreso Interamericano de Ingeniería Sanitaria y Ambiental, 27. ABES. pp. 1-10.

Symonds, E.M., Verbyla, M.E., Lukasik, J.O., Kafle, R.C., Breitbart, M. and Mihelcic, J.R. (2014). A case study of enteric virus removal and insights into the associated risk of water reuse for two wastewater treatment pond systems in Bolivia. Water Research. 65, doi: 10.1016/j.watres.2014.07.032.

Trein, C.M., Pelissari, C., Hoffman, H., Platzer, C.J. and Sezerino, P.H. (2015). Desempenho de um wetland construído 
vertical operando sob alta carga orgânica aplicada. Congresso Brasileiro de Engenharia Sanitária e Ambiental.

Verbyla, M.E., Oakley, S.M. and Mihelcic, J.R. (2013). Wastewater Infrastructure for Small Cities in an Urbanizing World: Integrating Protection of Human Health and the Environment with Resource Recovery and Food Security. Environmental Science and Technology. 47, pp. 3598-3605. doi: 10.1021/es3050955.

Verbyla, M.E. (2015). Pathogen Removal in Natural Wastewater Treatment and Resource Recovery Systems: Solutions for Small Cities in an Urbanizing World. University of South Florida. doi: 10.1017/CBO9781107415324.004.

von Sperling, M., Bastos, R.K.X. and Kato, M.T. (2005). Removal of E. coli and helminth eggs in UASB: Polishing pond systems in Brazil. Water Science and Technology. 51, pp. 91-7.

von Sperling, M., Chernicharo, C.A.L., Soares, A.M.E. and Zerbini, A.M. (2003). Evaluation and modelling of helminth eggs removal in baffled and unbaffled ponds treating anaerobic effluent. Water Science and Technology. 48, pp. 113-120.

von Sperling, M., Chernicharo, C.A.L., Soares, A.M.E. and Zerbini, A.M. (2002). Coliform and helminth eggs removal in a combined UASB reactor-baffled pond system in Brazil: performance evaluation and mathematical modelling. Water Science and Technology. 45, pp. 237-42.

von Sperling, M. and Mascarenhas, L.C.A.M. (2005). Performance of very shallow ponds treating effluents from UASB reactors. Water Science and Technology. 51, pp. 83-90.

WHO (2006). Volume II of the Guidelines for the safe use of wastewater, excreta and greywater: Wastewater use in agriculture. World Health Organization. France. pp. 196.

Yaya-Beas, R.E., Ayala-Limaylla, C., Kujawa-Roeleveld, K., van Lier, J.B. and Zeeman, G. (2015). Helminth egg removal capacity of UASB reactors under subtropical conditions. Water. 7, pp. 2402-2421.

Yaya-Beas, R.E., Cadillo-La-Torre, E.A., Kujawa-Roeleveld, K., van Lier, J.B. and Zeeman, G. (2016). Presence of helminth eggs in domestic wastewater and its removal at low temperature UASB reactors in Peruvian highlands. Water Research. 90, pp. 286-293. doi: 10.1016/j.watres.2015.11.023. 